\title{
Christian Worship at the Tomb of the Prophet Samuel on Mount Joy
}

\author{
PIOTR MIESZKO BRIKS \\ University of Szczecin \\ piotr.briks@usz.edu.pl \\ ORCID: 0000-0001-7929-2840
}

\begin{abstract}
One of the exceptionally interesting examples of a living biblical tradition, maintained by Christian, Muslim and Jewish pilgrims for over sixteen hundred years, is the history of St. Samuel monastery on the Mount of Joy. The shrine was founded in the Byzantine period, but its heyday falls on the period of the Crusades. It was from here, after the murderous journey, that the troops of the First Crusade saw Jerusalem for the first time. The knights were followed by more and more pilgrims. On the hill, called Mons Gaudii, the Premonstratensians built their monastery, which in time became a real pilgrimage center. Based on the preserved traces, the author reconstructs the Christian chapters of the history of Nabi Samuel. He recalls people, events and traditions related to it, and also the accounts of pilgrims coming here.Christians left the Mons Gaudii probably at the end of the 12th century. Worship of the prophet Samuel were taken over by Muslims and Jews. For the latter the Tomb of Prophet Samuel became one of the most important places of pilgrimage, in some periods even more important than Jerusalem itself. There were numerous disputes and conflicts about holding control over this place, there were even bloody battles. In 1967 this place was taken by the Israeli army. Over time, a national park was created in the area around the mosque, in the mosque itself was established a place of prayer for Jews, and a synagogue in the tomb crypt. A slightly forgotten sanctuary began to warm up emotions anew.
\end{abstract}

KeYwords: Nabi Samuel, Nebi Samuel, Nebi Samwil, Samuel, Rama, Mons Gaudii, maqam, cenotaph

$B^{i}$ ible commentaries were created and are still being written not only in scriptoria or on the monks' or exegetes' desks. Sometimes they arise from the memory of places, events and prayers of pilgrims. Polish Biblicists are well aware of this. Many of them are regular guests in the Holy Land, where they not only study, but also show pilgrims around, decoding the background of biblical events from places and local traditions.

One of the exceptionally interesting examples of a living biblical tradition maintained by pilgrims for at least 1600 years is the history of the monastery of St. Samuel, the prophet on Mount Joy (Mons Gaudii, Monjoie). Almost all pilgrims coming to Israel pass this place a few times: going from the airport to Jerusalem, returning the same way, travelling towards the Mediterranean Sea or Galilee. North of the motorway, $2 \mathrm{~km}$ as the crow flies, on a hill overlooking the area, 
the tall minaret of the Nabi Samuel (= Prophet Samuel, Shmu'el ha-Navī in Hebrew, al-Nabī Samwīl in Arabic) mosque is clearly visible. However, the majority of Christian groups pass this place indifferently. The Jewish and Muslim pilgrims devote definitely more attention to Nabi Samuel.

Since 1967, there has been a very fierce dispute over the title to this hill, involving the highest authorities of Israel and The Palestinian National Authority as well as numerous organisations with the United Nations Organization at the top of the list. This, of course, is not the first struggle for domination over the site of the Prophet Samuel's cult. Over the centuries this sanctuary has changed hands and several battles have been fought for its control. For centuries it has been alternately a church, a mosque and a synagogue. As a result of political decisions and military actions, it is currently within the territory of a national park, the boundaries of which contain relics from the consecutive chapters of the history of this place and a building located atop the hill - housing a mosque and a synagogue, everything placed within the walls of the church from the crusaders' times. However, no special place for prayer has been allocated to Christians. Nor does anybody voice such a need. The memory of the Christian origins of this sanctuary and the many centuries of Christian cult at the tomb of the Prophet Samuel has faded.

The aim of this study is to recreate the Christian chapters in the history of St. Samuel sanctuary. Due to the scarcity of sources many intriguing questions remain unanswered. Nevertheless, it is possible to create a relatively clear picture of the history of this fascinating place.

\section{The Beginnings of the Cult of St. Samuel}

According to 1Sam 25:1 and 28:3, the Prophet Samuel died surrounded by reverence, and his funeral had an extremely solemn character: Now Samuel died. And all Israel assembled and mourned for him, and they buried him in his house (בביתו) at Ramah... (1Sam 25:1). ${ }^{1}$

We know nothing of the fate of the prophet's tomb from the 11th century B.C. until the 5th century A.D. Considering such a long time of silence, the general nature of biblical data and the lack of other sources, one should accept the fact that the location of the prophet's authentic tomb, and even the location of the city where he was buried, remains unverifiable (as well as other traces of his activity). The suggested proposals are only assumptions, based on intuition rather than on

In 1Sam 1:1 Samuel's hometown is called "Ramathaim (Zophim)," and "Ramah" in the rest of Biblical texts. 
irrefutable evidence. However, one may try to recreate the Byzantine traditions associated with the identification of this place.

In 406, St. Jerome writes about the relocation of the "bones of the blessed Samuel" (ossa beati Samuelis) from Judea to Thrace on the orders of the Emperor Arcadius (395-408). ${ }^{2}$ The credibility of this account is supported by the fact that St. Jerome was residing in Bethlehem at that time, so he could have been an eyewitness at least to the beginning of the described events. Unfortunately, the Saint of Stridon does not specify whether everything that had been found in the tomb attributed to Samuel was taken to Constantinople, or whether it was only his relics. Neither does he specify a particular place from where the prophet's remains were thought to have been taken.

Two mentions in Eusebius' Onomasticon (305-324), translated and supplemented by Jerome (388), may provide some clue. According to 1Sam 1:1, (following the tradition of Greek translations) the "city of Elkanah and Samuel" is referred to as Armath (Seifa/Sofim), ${ }^{3}$ just as the pilgrim Arkulf (De Locis Sanctis) in the second half of the 7th century. In addition, Arkulf gives its location which is consistent with today's Nabi Samuel. ${ }^{4}$ In turn, elsewhere in Onomasticon, one may find the information that "Ramah in the tribe of Benjamin, the city of Saul, [is] 6 miles north from Aelia [= Jerusalem]." ${ }^{, 5}$ It seems, then, that already at the dawn of the Byzantine period, the biblical Ramah was located where the Nabi Samuel sanctuary stands today.

The information about the relocation of Samuel's remains that was provided by St. Jerome is repeated and elaborated in an anonymous work from the beginning of the 7th century known as the Chronicon Paschale. According to this source, the prophet's ashes were to have been brought from Palestine to Constantinople on 19 May 406. The convoy with the saint's remains was expected with a great longing, and he was greeted with great reverence along the way. Samuel's relics were brought into the city at 2 am by the Emperor Arcadius himself together with the nobles who surrounded him; and they were deposited in

2 Jerome, Contra Vigilantium V, 11-12. In V, 12 he speaks of bones gathered in a golden vase and covered with silk. Hieronymus, "Liber contra Vigilantium," Sancti Eusebii Hieronymi, Stridonensis Presbyteri, Opera omnia (ed. J.P. Migne) (PL 23; Paris: Migne 1845) 343.

3 P. de Lagarde (ed.), Onomastica sacra (Gottingae: Rente 1870) 225-226. In the Hebrew Bible the

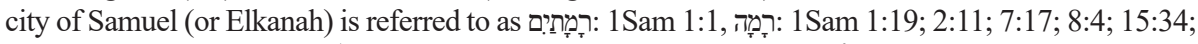

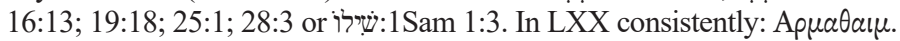

4 D. Meehan (ed.), Adamnan's De Locis Santis (Scriptores Latini Hiberniae 3; Dublin: Dublin Institute for Advanced Studies 1983) 65. Around the area of today's Nabi Samuel, the town of Armathemi is marked on the Madaba Map (6th century). Perhaps (according to other Byzantine sources), it is identical to Arimathea located below. It should be emphasized, however, that the accuracy of the Madaba Map is rather arbitrary and it is difficult to draw any binding conclusions on its basis.

5 According to the measure adopted in Onomastica, it is approx. 9-10 km. Lagarde, Onomastica sacra, 146. 
the Church of Hagia Sophia ("in the Great Church"). ${ }^{6}$ In October 411, the relics were relocated to the church built expressly for this purpose in Hebdomon on the outskirts of Constantinople. ${ }^{7}$ This temple was destroyed during the earthquake on 14 December 557 and was no longer mentioned in the documents. ${ }^{8}$ Neither is it known what happened to the relics of the prophet which were kept in this place.

\section{The Byzantine and Early Arabian Period (6th-11th Centuries)}

The archaeological research shows that in the 4th century A.D., a Christian settlement was established in the area of today's Nabi Samuel. It was concentrated around a chapel or a church and a monastery, in which there could have also been a dormitory for pilgrims. Numerous coins from the Byzantine period (some of them from areas distant from Israel) are the traces of pilgrims who used to frequent this place at that time. It is probably the monastery which is meant by Procopius of Caesarea (ca. 550), who mentions that the Emperor Justinian I (527-565) built a well and the walls "around the monastery of St. Samuel in Palestine" (without specifying its location). ${ }^{9}$ Little remained from the Byzantine buildings. Only fragments of walls (probably those from the times of Justinian) and one decorated column base. ${ }^{10}$ In the vicinity, several things were preserved: the ruins of a large workshop, a part of a wine press, fragments of floor inlays and houses from the 5th-6th centuries A.D., which functioned until the early Muslim period of the 8th-10th centuries. The rest of the remains of the buildings were removed during the construction works in the crusaders' period.

It is not known why this particular place was chosen to commemorate the prophet, Samuel. During the archaeological excavations in Nabi Samuel,

6 M. Whitby - M. Whitby (trans., eds), Chronicon Paschale 284-628 AD (Translated Texts for Historians 7; Liverpool: University Press 1989) 60.

7 Nicephorus Callistus Xanthopulus (c. 1256 - approx. 1335): Nicephori Callisti Xanthopuli Ecclesiasticae Historiae (ed. J.P. Migne) (PG 146; Parisiis: Migne 1865) lib. XIV, c. X, p. 1090.

$8 \quad$ For the history of the transfer of Samuel's remains and their subsequent fate, see: H.A. Klein, "Sacred Relics and Imperial Ceremonies at the Great Palace of Constantinople," Visualisierungen von Herrschaft. Frühmittelalterliche Residenzen - Gestalt und Zeremoniell (ed. F.A. Bauer) (BYZAS 5; İstanbul: Ege Yayınları 2006) 84. As an interesting fact, it is worth noting that in Constantinople, the church of Nea Ekklesia was supposed to have been the place of storing the horn from which the Prophet Samuel anointed David as king. Ibidem, 92.

9 Procopius, De Aedeficiis, Fr. V, IX, 15: On Buildings (trans. H.B. Dewing - G. Downey) (LCL 343; Cambridge, MA: Harvard University 1940) 359.

$10 \quad$ R. Savignac - F.M. Abel, "Neby Samouil," RB ns 9/2 (1912) 271. 
the explorers did not find any traces of the earlier Jewish cult of the prophet. ${ }^{11}$ Moreover, to this day, explorers have found no evidence which would suggest that this place was inhabited during the period of Samuel's activity. ${ }^{12}$ The first traces of settlement date back to the Second Iron Age (1000-550 B.C.).

It is not known either when one of the caves on the hill came to be regarded as the tomb of the prophet. The first mention of Samuel's tomb appears in this place only in 520-530, in Theodosius' report on his trip to the Holy Land - De situ terrae sanctae. He writes about "...Ramatha, where Samuel rests (requiescit)," and he mentions that the burial site of the prophet is located approx. 5 miles $(7.5 \mathrm{~km})$ from Jerusalem, which is exactly the same as the distance to today's Nabi Samuel. ${ }^{13}$

About the cult of the Prophet Samuel during the Byzantine period, as well as perhaps even later, we learn from the elements of pottery (the most numerous ones in situ from the 8th century) on which the Arabic inscriptions Dayr (monastery) Samwīl / Šamwīl or min Dayr Samwil (from the monastery of Samuel) were impressed. ${ }^{14}$ Among the ruins from the early Muslim period, numerous kilns for firing ceramics as well as tools and materials for its production have been found. Products from Dayr Samwil, particularly vessels used for the storage and transport of food, have been found in Caesarea, Ramla, and Jerusalem. Therefore, it can be concluded that either the monastery itself was still functioning or its memory was still alive.

The existence or memory of the existence of a (unspecified) monastery/church in this place at the end of the 10th century is also mentioned by the Arab traveller

11 See: M.J. Breger - Y. Reiter - L. Hammer (eds.), Sacred Sites in the Holy Land: Historical and Religious Perspectives (The Hague: Institute for Historical Justice and Reconciliation 2011) 86. Nevertheless, Yoel Elitzur believes that the Byzantines Christianized a place of undetermined cult that previously existed here, and it owes the relationship with the Prophet Samuel solely to the memory of his activities in that area (Shiloh, Ramah, Mizpah). See: Y. Elitzur, 'מקור המסורת על 'נבי סמואל (Sources of the 'Nebi-Samuel' Tradition"), Cathedra 31 (1984) 75-90, and also on the variety of names of this place (pp. 77-79).

12 In 1980, the Israelis conducted the first archaeological research under Amir Feldstein's direction (A. Feldstein et al., "Southern Part of the Maps of Ramallah and el-Bireh and Northern Part of the Map of Ein Karem," Archaeological Surveys in the Hill Country of Benjamin [eds. I. Finkelstein - Y. Magen] [Jerusalem: Israel Antiquities Authority 1993] 232-233 [Hebrew, extensive English abstract]). Even then, attention was drawn to the lack of traces of settlement in this place in the hypothetical period of Samuel's activity (out of the 221 pieces of pottery that were discovered at that time, only one was dated back to the Iron Age I). These findings were confirmed by the excavations carried out in 1992-2003 under Dr. Yitzhak Magen's direction (Y. Magen, "Nebi Samwil: Where Samuel Crowned Israel's First King," BAR 34/3 [2008] 36-45, 78-79).

13 Theodosius, De situ terrae sanctae 34. Cf. J.H. Bernard (trans.), Theodosius (The Library of the Palestine Pilgrims' Text Society; London: PPTS 1893) 10. (also: P. Geyer [ed.], Itinera Hierosolymitana saeculi IIII-VIII [CSEL 38] [Vindobonae: Tempsky 1898] 140). Cf. Elitzur, 'מקור המסורת על 'נבי סמואל, no. 56.

14 M. Sharon (ed.), Corpus Inscriptionum Arabicarum Palaestinae (Leiden - Boston, MA: Brill 2004) III, 126-128. 
and geographer al-Muqaddasi (died in 988). He wrote down an anecdote that he had been told by his uncle (Abdullah ibn ash Shawâ). It says that a certain sultan wanted to buy (a village), namely Dayr Samwil, which is located near Jerusalem. He asked the current owner/administrator (?) for a description of the area. The man replied: My village, may Allah bring you assistance, comes from heaven, it is located high above the lowlands; sparsely endowed with harvest, rich in weeds; hard bread is eaten there (the work is hard), you will not enjoy a great profit, everything is overgrown with corncockle, and almonds are bitter; you sow one bushel, you harvest one bushel, still the grain you sowed was of better quality. This sacred place, in turn, is full of pits. And the sultan cried: Go away! We want to have nothing to do with your village. ${ }^{15}$

The word dayr, which occurs in al-Muqaddasi's account, as well as the lack of a direct mention of any mosque, seem to indicate at least that there was no Muslim sanctuary functioning there. This is all we know about the 461 years of history of this place after the conquests of caliph Omar's army. It can only be emphasised that during all these years the memory of his relationship with the Prophet Samuel was maintained.

\section{The Crusaders Period}

\subsection{Mount Joy}

This place became famous again at the very beginning of the Crusades era in the Holy Land. It was from here that the knights of the First Crusade, on 7 June 1099, after three years of excruciating wandering, saw Jerusalem for the first time and "everyone burst into tears of joy." 16 The medieval name of this

15 Difficult text, translated in various ways. M.J. de Goeje, Biblioteca Geographorum Arabicorum (Leiden: Brill 1870) III, 188. Cf. P. Schwarz, "En-nebi Samwil in einer Schilderung bei Mukaddasi," ZDPV 41/3-4 (1918) 157-161 and the translation of G. Le Strange, Palestine under the Moslems. A Description of Syria and the Holy Land from A.D. 650 to 1500 (London: Watt for the Committee of the Palestine Exploration Fund 1890) 433. On the subject of Nabi Samuel within the period before the crusaders cf.: P. Lohmann, "Studien aus dem Deutschen evang. Institut für Altertumswissenschaft in Jerusalem. 29. Archäologisches von en-nebi samwīl," ZDPV 41/3-4 (1918) 145-146;

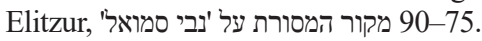

16 Albertus Aquensis, "Alberti Aquensis Historia Hierosolymitana," Recueil des historiens des croisades. Historiens occidentaux (Paris: Imprimerie nationale 1879) IV, 463: "Jerusalem vero nominari audientes, omnes prae laetitia in fletum lacrymarum fluxerunt, eo quod tam vicini essent loco sancto desideratae urbis, pro quo tot labores, tot pericula, tot mortis genera perpessi sunt." Nabi Samuel on the threshold of the era of the Crusaders cf. H.E. Mayer, "Sankt Samuel auf dem Freudenberge und sein Besitz nach einem unbekannten Diplom König Balduins V," Quellen und Forschungen aus italienischen Archiven und Bibliotheken 44 (1964) 36-37; H.E. Mayer, Kreuzzüge und lateinischer 
hill: "Mount Joy" is generally accepted to have been derived from this particular event. The fact is, however, that such aetiology appears in documents much later. Acc. to Aubrey Stewart, only in 1670 in Voiage nouveau de la Terre Sainte by Seigneur de la Croix: "is it called Montjoie, because it was from here that the Crusaders saw the holy city for the first time." ${ }^{17}$ It is also worth mentioning here that the name was not always associated with the sanctuary of the Prophet Samuel's tomb and it probably referred to other hills/places in the vicinity of Jerusalem as well. ${ }^{18}$ On the other hand, the tradition of deriving the name "Mons Gaudii - Mount Joy"19 from the joy of arriving pilgrims is confirmed much earlier in the diary from the trip to the Holy Land from the beginning of the 14th century, 'The Travels of Sir John Mandeville. ${ }^{.20}$ He writes: Two miles from Jerusalem rises Mount Joy (mons vocatur Exultationis vel Lœtitiae - ab aliis Gaudii), a very beautiful and delicious place. This is where the Prophet Samuel lies in a beautiful tomb. This place is called Mount Joy (Mons Gaudi) because it rejoices the hearts of pilgrims who can see Jerusalem for the first time from here.

A similar interpretation of the name of this hill was left by the Swiss Dominican Friar, Felix Fabri (in the Holy Land 1480 - 1483 A.D.): "in ancient times, pilgrims were always led to Siloh, from where they could see Jerusalem full of joy. That is why this place used to be called the joy of pilgrims." He supplements his account with a description of the place: "And when we were in the place [called] Siloh,

Osten (London: Variorum 1983); J. Prawer, Histoire du Royaume latin de Jérusalem (trans. from Hebrew G. Nahon) (Paris: CNRS 1975) II, 222, 667, note 49; J. Prawer, The History of the Jews in the Latin Kingdom of Jerusalem (Oxford: Clarendon Press 1988) 203-204. Doubts about the identification of Mons Gaudii, from which the crusaders saw Jerusalem for the first time, with the burial site of Samuel, cf. M. Ehrlich, "The Route of the First Crusade and the Frankish Roads to Jerusalem during the 12th Century," $R B$ 113/2 (2006) 264-272.

17 Aubrey Stewart draws on the work of Le Seigneur de la Croix, "Voiage Nouveau de la Terre Sainte"1670 A.D. ("Theoderich's Description of the Holy Places" [The Library of the Palestine Pilgrims' Text Society; London: PPTS 1891] V/4, 58, no. 3). However, I failed to find either this book or any other with a similar date of publication that would include the information provided by Stewart. Although in 1679 the book by Michael Nau(d) was published under the same title Voyage nouveau de la Terre-Sainte. Enrichi de plusieurs remarques particulieres qui servent à l'intelligence de la Sainte Ecriture (Paris: Pralard 1679), I did not find there any fragment from which A. Steward could have copied his quote (cf. no. 42).

18 On the various identifications of Mount Joy, cf. B.Z. Kedar, "Jerusalem's Two Montes Gaudii," Crusader Landscapes in the Medieval Levant. The Archaeology and History of the Latin East (eds. M. Sinibaldi et al.) (Cardiff: Universtiy of Wales 2016) 6-14. Extensive study presenting different possible locations: S. Gibson - M. Har-Pele, "On the Location of Mons Gaudii in Northern Jerusalem," Strata 37 (2019) 113-140. The authors believe that although M. Scopus has a better view of Jerusalem than the places located more to the west, climbing it would require going off the trail leading straight to Jerusalem.

19 On the subject of medieval traditions of giving the name Mons Gaudi to the mountains or hills with sanctuaries that were visited by pilgrims or places from which the pilgrimage destination could be seen, cf. Kedar, "Jerusalem's Two Montes Gaudii," 4-5.

20 T. Wright, Early Travels in Palestine (London: Woodfall \& Son 1848) 175. 
we saw great ruins of old walls and churches standing on the top of the mountain until today, then turning our eyes to the east, we were looking at the holy mountain, a wonderful mountain, the Mount of Olives and at the Church of the Ascension on its top. At that time, we could not see the holy city, even though it was closer to us than the Mount of Olives." ${ }^{21}$ In the course of time the tradition of thanking God for the endured journey in this place was established. ${ }^{22}$

Whatever its aetiology, the name Mons Gaudii (Montjoie) Mount Joy appears in the official documents as soon as at the very beginning of the kingdom of Jerusalem. King of Jerusalem, Baldwin I (1100 - 1118 A.D.), in 1115 A.D. confirmed the donation of the land that was located in the vicinity of Mount Joy in favour of the abbey of Our Lady of [valley] Jehoshaphat (= Mary's Tomb in the Kidron Valley). ${ }^{23}$ This name appears also in the confirmation of the deeds of donation issued by Baldwin II in $1120 .{ }^{24}$ However, it is not certain whether both of these cases are associated with the same Mount Joy. There are serious indications whereby, at least in the 12th century, the name was also associated with the hill located to the northeast of Jerusalem by the main road from Nablus and Mahumeria, or more generally, to the hills north of Jerusalem. ${ }^{25}$ Only at the turn of the 12 th and 13th centuries, perhaps due to the conquest of the centre of the country by Muslims, and thus, due to the change of pilgrimage routes (for the safer ones), it was the hill with the Sanctuary of Samuel (now: Nabi Samuel) which was more often referred to as Mount Joy. ${ }^{26}$

Since the arrival of the crusaders, the sanctuary became a place of the Christian cult again, although it is worth noting that this time under the protection of the Western Christians - referred to as the Latin Christians or Franks in the Holy Land. However, the Holy Land that was regained for Christians was also visited by the pilgrims from the East. One of them, Archimandrite Daniel, also known as the Traveller or Pilgrim, wrote down the memories from his stay at the place of birth and burial of the Prophet Samuel, which was known to him by the Byzantine name Armathaim (1106): There is a very high hill which is located near

21 A. Stewart (trans.), Felix Fabri (Circa 1480-1483 A.D.) (The Library of the Palestine Pilgrims' Text Society 7; London: PPTS 1896) 277.

22 W. Stubbs (ed.), Itinerarium peregrinorum et gesta regis Ricardi (London: Longman 1864) 435.

23 Cf. H.F. Delaborde, Chartes de Terre Sainte Provenant de l'Abbaye de N.-D. de Josaphat (Paris: Thorin 1880) 29 (doc. VI).

24 Delaborde, Chartes de Terre Sainte Provenant, 34 (doc. VIII).

25 G. Dalman, Jerusalem und sein Gelände (Gütersloh: Bertelsmann 1930) 30; F.-M. Abel, "Attarah et Nasbeh au moyen âge," JPOS 11 (1931) 141-143; D. Pringle, The Churches of the Crusader Kingdom of Jerusalem. A Corpus (Cambridge: Cambridge University 1993) II, 44; Kedar, "Jerusalem's Two Montes Gaudii," 3-19. A slightly different conception of Mons Gaudii is proposed by Gibson Har-Pele, "On the Location of Mons Gaudii in Northern Jerusalem," 113-140. They claim that located directly north of Jerusalem Mons Gaudii is not a specific place (e.g. a sanctuary) but "a district or locale on the north side of Jerusalem" (p. 113).

26 Kedar, "Jerusalem's Two Montes Gaudii," 13. 
Jerusalem, on the right side of the road leading to Jaffa [...] This is the hill where the tomb of the Prophet Samuel, his father Elkanah, and Mary of Egypt ${ }^{27}$ is located, and everything is surrounded by a wall. And further: in this place, travellers dismount their horses, and every Christian enjoys the view of the Holy City. ${ }^{28}$ Due to the fact that there still was not a Crusaders' church on this site, Daniel must have visited a place that was held sacred since the Byzantine period.

\subsection{Sanctuary of the Tomb of Samuel}

Specific activities aimed at erecting a sanctuary of St. Samuel were undertaken during the reign of Baldwin II (1118-1131 A.D.), who intended to donate 1,000 gold coins (aureos) to the Cistercians in order to build a monastery at the prophet's tomb. ${ }^{29}$ Of course, the donation included the very area of Mount Joy, the unspecified buildings located there, as well as freedom of trade and exemption from levies. ${ }^{30}$ However, Baldwin's plans were thwarted by the refusal of the then Cistercian abbot Bernard of Clairvaux. He was afraid of pagan (i.e. Muslim) attacks and "the uncertainty of the weather" (without specifying what exactly this reservation was about). ${ }^{31}$ Eventually, as requested by Bernard, both the place and money for the construction went to the Norbertines (Premonstratensians), who were Cistercians' friends, ${ }^{32}$ and at the same time, one of the most dynamically developing orders of the 12 th century.

In 1140 , the construction of fortifications $(67 \times 100 \mathrm{~m})$, which were intended to protect the future monastery, was started. The ground was surrounded by 2 -metre

27 Mary of Egypt, hermitess, lived at the turn of the 4th and 5th centuries. Her birthplace was Alexandria, Egypt. She died ca. 421 in the desert near Jericho, where, in accordance with Byzantine tradition, she was buried. It is difficult to say from where Daniel obtained information about the tomb of Mary of Egypt which is located in the crypt of Samuel's tomb.

28 C.W. Wilson, The Pilgrimage of the Russian abbot Daniel in the Holy Land (The Library of the Palestine Pilgrims' Text Society; London: PPTS 1895) 9.

29 Perhaps the mention in the letter of St Bernard to the patriarch of Jerusalem from ca. 1135 refers to the plans of creating a Cistercian abbey at the Tomb of the Prophet Samuel: De loco autem, ad quem nos invitatis, frater Andreas dicet vobis voluntatem nostram ("Letter 175," PL 182, 337).

30 Mayer, "Sankt Samuel," 57.

31 Godfrey of Clairvaux: "...in terram Jerosolymitanam, quamvis locus esset a rege paratus, ob incursus paganorum et aeris intemperiem non acquievit mittere fratres suos." D.J. Mabillon [ed.] "Gaufridus Claraevallensis. Vita Bernardi. Liber III," PL 185, 316). A few decades later, Cistercian monasteries in Ein Karim and probably in 'Allar as-Sufla were established. Cf. Pringle, The Churches of the Crusader 1, no. 8 and 9.

32 This fact is mentioned by St Bernard of Clairvaux in the letter to the Norbertines' prior, Hugon, which is dated at 1150 ("Apud Jerosolymam rex Balduinus, dum adhuc viveret, locum Sancti-Samuelis donavit nobis, et mille aureos simul, de quibus aedificaretur: vos dono nostro et locum habetis, et aureos habuistis"): "Letter 253," PL 182, 454. For a discussion on this topic cf. Mayer, "Sankt Samuel," 37-39 and Mayer UKJ I, 280-281. 
thick and 5-metre-high walls with four towers. ${ }^{33}$ It was also the beginning of carving a rock moat. The material for the construction of the fortifications came from the demolition of the earlier buildings and from the local quarry, which, after removing the stones, was used as stables, dormitory and water reservoirs. The fortress also had underground storage rooms. However, the construction of the fortifications could not be completed. To this day, there are visible huge stone blocks, pre-processed in quarries, which were not extracted from them or used to strengthen the ramparts of the fortress. The construction of the moat was not completed either.

The Norbertine abbey itself began to be developed here in 1141 or $1142^{34}$ This date, however, is sometimes questioned. In the Premonstratensian calendar, edited in 1175-1178 A.D., there is a note on 10 February, which says: "Commemoratio... domni Balduini Jherosolimitani regis, fundatoris ecclesiae sancti Samuelis." On 10 February 1163 Baldwin III died. This could indicate that the founder of the abbey was not Baldwin II, but only his grandson Baldwin III of Jerusalem. On the other hand, the record from the diploma of Baldwin V clearly states that the donor of Mons Gaudi to the Premonstratensian Order was "Balduinus... Latinorum rex secundus" (d. 25.08.1131) ${ }^{35}$ and it is rather him who should be credited with the foundation of the monastery, although undoubtedly Baldwin III also contributed significantly to its development. ${ }^{36}$

In 1142, the daughter of Baldwin II, Queen Melisende of Jerusalem (1131-1153), a generous donor, was entreated to receive the monks warmly and support the venture in a letter written by St. Bernard of Clairvaux himself. ${ }^{37}$

33 Larger ones from the southwest $(6 \times 7 \mathrm{~m})$ and south $(6 \times 6 \mathrm{~m})$ and smaller ones: from the northwest and a tower protecting the square in the courtyard of the fortress from the east.

34 E.G. Rey, Géographie historique de la Syrie au temps des croisades. Le domaine royal. Les colonies franques de Syrie aux XIIme et XIIIme siècles (Paris: Alphonse Picard 1883) 391. For more information about the monastery of St Samuel under the government of the Norbertines (Premonstratensians), cf. Pringle, The Churches of the Crusader 2, 85-94. Archaeological data: Y. Magen M.M. Dadon, "Nebi Samwil (Montjoie)," One Land, Many Cultures. Archaeological Studies in Honour of Stanislao Loffreda (eds. G.C. Bottini - L. Di Segni - L.D. Chrupcala) (Jerusalem: Franciscan Printing 2003) 123-138 and Lohmann, "Archäologisches von en-nebi samwīl," 117-157.

35 A document dated at 1125 contains a mention of an unidentified "St Samuel's abbot in Acre." The Premonstratensians moved to Acre only after the seizure of St Samuel by the Muslims in 1187. Moreover, there are no other traces of the existence of any monastery of St Samuel in Acre. It is not known, therefore, whether we are dealing here with a mistake or whether the Premonstratensians temporarily settled in Acre, and then they set off to Mount Joy (J. Delaville le Roulx, Cartulaire générale des Hospitaliers de l'Ordre de St Jean de Jérusalem [Paris: Leroux 1894] I, 69 [doc. 72]).

36 Mayer, "Sankt Samuel," 38-39.

37 J. Leclercq - H. Rochais (eds.), Sancti Bernardi Opera (Rome: Cisterciennes 1979) VIII, 355. See also: J. Folda, "Melisende of Jerusalem: Queen and Patron of Art and Architecture in the Crusader Kingdom," Reassessing the Roles of Women as 'Makers' of Medieval Art and Architecture (ed. T. Martin) (Leiden: Brill 2012) 473, sources in the footnote 98. The date of the letter is uncertain - cf. Mayer, "Sankt Samuel," 38. 
Probably it was owing to her help in large part that the church and monastery buildings were completed. ${ }^{38}$

The construction of the monastery was commenced several years later, when its safety was already secured by a newly built fortress. In this place, the monastery started to function no later than in 1156-1157, at least from then on it was mentioned in the documents of the Church of the Holy Sepulchre. For the first time, on the occasion of the dispute between the canons of the Church of the Holy Sepulchre and the canons from the Mount of Olives, in which the abbot "R... Sancte Samuelis" was one of the conciliators. ${ }^{39}$ In 1157, Arnaldus, prior of the Church of the Holy Sepulchre, purchased a vineyard from one Guibert Papasio, which was located "by the cemetery of the Church of St. Samuel." ${ }^{40}$ From the 12th century documents, we know the names of two abbots of St. Samuel of Mount Joy: Theoderich (d. on March 24) and Hugo (d. on 25 August). ${ }^{41}$

The traditions of the Prophet's tomb and information about the functioning of the monastery in this place are confirmed shortly afterwards (approx. 1172) by a German monk Theoderich in Libellus de locis sanctis, a guide to the holy places in Palestine. According to his account, the tomb of Samuel was on Mount Shiloh (Sylo), which, as he reports, changed its name to "the place at St. Samuel's" (locus ad sanctum Samuelem) and where a community of monks called grey ones (grisi) exists. ${ }^{42}$ Hans E. Mayer believes ${ }^{43}$ that this is not a reference

38 Mayer, "Sankt Samuel," 35-71 (particularly: 38-39, 55, 59-61, 68-69). Also: B. Hamilton, "Rebuilding Sion: The Holy Places of Jerusalem in the Twelfth Century," SCH 14 (1977) 105-116 (particularly: 113-114 and no. 74).

39 E. de Rozière, Cartulaire de l'Eglise du Saint Sépulcre de Jérusalem (Paris: Imprimerie Nationale 1849) 136 (doc. 66).

40 Rozière, Cartulaire, 239 (doc. 129): “Arnaldus... quamdam etenim fecit commutationem cum Guiberto Papasio de quadam videlicet vinea, quam prefatus Guibertus libere habebat et possidebat juxta ecclesiam Montis Gaudii, cimiterio videlicet eiusdem ecclesie coniunctam." (original spelling). The same document also mentions the sale of a vineyard to Martin Carpentario [from] Monti Gaudi by one Ainard.

41 Mayer, "Sankt Samuel," 42, footnote 31.

42 T. Tobler (ed.), Theoderici libellus de locis sanctis, ed. circa 1772, cui accedunt breviores aliquot descriptiones Terrae Sanctae (Paris: St. Gallen 1865) 88-89. See also: A. Stewart (trans.), Theoderich's Description of the Holy Places (Circa 1172 A.D.) (The Library of the Palestine Pilgrims' Text Society; London: PPTS 1891) V/4, 4 (no. 1) and 58 (particularly the aforementioned note 3, which includes the publisher's note about the fortifications, the monastery and the monks on the Mount Montjoie, cited after the unconfirmed publication of Le Seigneur de la Croix, "Voiage Nouveau de la Terre Sainte," (cf. no. 17): “... this order derives its roots from devout Christians who built strong fortifications on the mountain between Ramah and Jerusalem, called Mount Joy, because of the fact that it was the place from which the crusaders saw the Holy City for the first time. They assisted the pilgrims in their journey. They lived according to the rule of St Basil and wore green (?) habits with a green star-shaped cross." He also mentions that they later emigrated to Spain). Theoderich's account also contains the name "Mons Gaudii" but he locates this place at the front of the Josaphat (Cedron) Valley - he probably refers to Mount Skopus (T. Tobler, Theoderici libellus de locis sanctis, 6).

43 Mayer, "Sankt Samuel," 40-41. 
to the Premonstratensians, but to the Order of the Knights of the Virgin Mary from Mount Joy led by Count Rodrigo Álvarez de Sarria, who, as it might be concluded from the papal bull of Alexander III of 1180, approving the order and granting the Rule of St. Bernard thereto, had his estate here - a monastery and a church: domus Montis Gaudii de Jherusalem et ecclesia vestra, quam apud prefatam domum edificare cepistis, and in another place: domus milicie Templi sancte Marie Montis Gaudii de Jherusalem. ${ }^{44}$ However, no one has yet identified the remains of the second (?) monastery and church in Nabi Samuel. In the documents, no records have been preserved about the change of the master of the sanctuary until the expulsion of the Crusaders from this site in 1187 by Saladin's army. Nevertheless, there are numerous documents confirming the efforts of the Premonstratensians to regain the monastery and church on Mount Joy (even in the 13th century). It is highly unlikely that the takeover of the Monastery of St. Samuel by the Order of Virgin Mary from Mount Joy left no traces in the documents. Perhaps the solution to this problem may be the assumption that the order of Count Rodrigo held its estate on another mountain of the same name, much closer to Jerusalem (which is suggested in the document of Pope Alexander: "extra muros civitatis Jherusalem" (outside the walls of the city of Jerusalem). ${ }^{45}$ Either way, the establishment of the Order of Knights (Virgin Mary) of Mount Joy (Orden de Monte Gaudio, in Latin documents Ordo/Sancte Marie/Montis Gaudii) is associated with the count's stay at the monastery of St. Samuel. ${ }^{46}$

Only one Arab reference to the sanctuary of the Prophet Samuel from this period has been preserved. Mâr Samuîl or Mârân Samuîl is mentioned by a Syrian traveller and writer Yakut Ibn Abdallah al-Hamawi (1179-1229) at the same time explaining: [it is] a small town in the vicinity of Jerusalem. Mar means $a$ [Christian] priest in Syrian, and Samuil is the name of one [of the Jewish] scholars of law (ạ̣bār). ${ }^{47}$ In turn, the Jewish traveller and pilgrim Benjamin

44 J. Delaville le Roulx, "L'Ordre de Montjoye," Revue de l'Orient Latin 1 (1893) 51-54. The name of the order or the monastic brothers (the church? of Virgin Mary) of Mount Joy also appears in other documents from the turn of the 12th and 13th centuries (pp. 51-57). For more information concerning the origins of the Order of Mount Joy in the Kingdom of Jerusalem, see Pringle, The Churches of the Crusader 2, 43-44.

45 R. Röhricht (ed.), Regesta Regni Hierosolymitani (MXCVII-MCCXCI) (Oeniponti: Libraria Academica Wageriana 1893) 146, no. 561. Cf. Pringle, The Churches of the Crusader 2, 44; Gibson Har-Pele, "On the Location of Mons Gaudii in Northern Jerusalem," 119-120.

46 Cf. Delaville le Roulx, "L'Ordre de Montjoye," 42 or A.J. Forey, "The Order of Mountjoy," Speculum 46/2 (1971) 253.

47 G. Le Strange (trans.), Palestine under the Moslems. A Description of Syria and the Holy Land from A.D. 650 to 1500 (London: Watt for the Committee of the Palestine Exploration Fund 1890) 433. Moshe Sharon (Corpus Inscriptionum Arabicarum Palaestinae, 114) rightly notices that this is an incorrect explanation, and the name comes from the Aramaic word $m \bar{a} r$ which is commonly accepted in Palestine and which means "holy." 
of Tudela ${ }^{48}$ (ca. 1173) noted: ...When the Christians took Ramlah, ${ }^{49}$ the old one, from the hands of Mohammedans, they found the tomb of Samuel the Ramatite there, not far from the Jewish synagogue. The Christians took him out (הוציאוהו) and brought him to Shiloh where they erected a large place of worship over him and named it Saint Samuel of Shiloh, and it has been so until today. ${ }^{50}$

However, one should be aware of the fact that this is an account of the events approx. 70 years prior thereto and there are many indications that it is only one of the traditions harmonizing the cult of the prophet's tomb on Mount Joy with the biblical story placing his burial in Ramah, which Benjamin identifies with Ramla. The city we know today under this name was founded ca. 715 A.D. By all means, it could not have had anything to do with the life of Samuel, nor with the place of his burial. It cannot be ruled out that the Jews, for reasons unknown to us, pointed to a tomb in Ramla, and the Crusaders believed that it was the Prophet's tomb. Therefore, they brought the remains of the person buried there to the sanctuary dedicated to the memory of Samuel, thus reviving the cult of this place. The contemporaries of Benjamin of Tudela, Jewish pilgrims Yaakov Ben Netanel HaCohen ${ }^{51}$ and Petachiah of Regensburg, ${ }^{52}$ do not mention the existence of Samuel's tomb on Mount Joy, while others questioned its authenticity. ${ }^{53}$ On the other hand, no one but Benjamin of Tudela mentions the tradition of Samuel's tomb at Ramla. There are also no records of his cult there. ${ }^{54}$

48 Jewish traveler from the 12th century. He travelled to the places of residence of the confessors of the Jewish faith in order to assess their number. He visited, among others, Palestine, where he visited Jewish settlements and in the places known from the Bible. For descriptions of his journeys, see A.K. Dulska, Diaspora żydowska na Bliskim Wschodzie oczami sefardyjskiego podróżnika Beniamina z Tudeli (Kraków: Księgarnia Akademicka 2015).

49 Benjamin of Tudela assumes that the ancient Ramah, which is the burial place of Samuel, is actually a different town - Ramla. On the other hand, Burchard (1274-1285) and Riccoldo (1288-1289) equate Ramla with Arimathea - cf. Burchardus de Monte Sion, "Descriptio Terrae Sanctae," Peregrinatores medii aevi quatuor (ed. J.C.M. Laurent) (Leipzig: Hinrichs 1864) 77-78; Riccold de Monte Croce, Pérégrination en Terre Sainte et au Proche Orient (ed., trans. R. Kappler) (Paris: Champion 1997) 72.

50 According to M.N. Adler (ed.), The Itinerary of Benjamin of Tudela. Critical Text, Translation and Commentary (Londyn: Oxford University 1907) 42.

51 Journeying on a pilgrimage to the Land of Israel between 1153 and 1187

52 He arrived in the Holy Land after 1175 and before 1187. For both, see A. Dawid, "Jewish Travelers from Europe to the East. 12th - 15th centuries," MEAH S.Hebr. 62 (2013) 11-39.

53 As the examples Elchanan Reiner presents the opinions of Isaac Latif (1480s), Moses Bassola from Pissaro (1521-1523) and a fragment of the so-called Scroll from Genizah (end of the 15th or beginning of the 16th century). Cf. 1517-1099 ועלייה לרגל לארץ ישראל (Pilgrims and Pilgrimage to Eretz Yisrael 1099-1517) (Diss. Hebrew University; Jerusalem 1988) 310.

54 Elitzur, 'מקור המסורת על 'נבי סמואל, 81. 


\subsection{The Monastery and Its Estates}

Apart from the already mentioned Queen Melisende, other rulers of Jerusalem also assisted in the maintenance of the abbey. Fulk V of Anjou (1131-1143) donated to the monastery the nearby casale of Bethania (probably Beth Hanina). The property of the order also included monasteries in Jerusalem (one of them was located at the so-called Tower of David, the second one at the Arch of Judas in southern Jerusalem ${ }^{55}$ ), a field by the road from al-Birah to Jerusalem (of which we learn that it belonged to a Greek monastery during Muslim times). ${ }^{56}$ In 1153, Baldwin III (perhaps the above-mentioned entry in the calendar stems from it) donated estates in Ashkelon ${ }^{57}$ and an annual rent of 200 Bezants $^{58}$ to the abbey, which was to be collected from the revenue of Acre. ${ }^{59}$ In Acre, the Premonstratensians of St. Samuel also owned a house which had been given to them by the Homo Dei family, towers in the city walls and a cellar (camera) bought from Peter Filot. The convent of St. Samuel also owned a part of the coast near Jaffa - the port which was the starting point of the pilgrimage route to Jerusalem, and several fields donated or purchased for the needs of the monastery. King Amalric I (1162-1174) donated to the Premonstratensians a lavishly appointed chapel of St. Longinus in Jerusalem. ${ }^{60}$ Moreover, casale St. Salvator near Blanchegarde with the associated lands. In Blanchegarde alone, the monastery of St. Samuel owned several houses with cellars, farmyards and gardens, and, in its vicinity, another piece of land (donated by Peter of Blanchegarde, later a monk at St. Samuel) and a cellar (camera) nearby. Near Ibelin, a farmyard with a cistern, garden and arable land.

According to H.E. Mayer, ${ }^{61}$ in 1185 - i.e. during the period of greatest prosperity, and two years before the Saladin's invasion, the community of St. Samuel owned, apart from its own monastery and church, two other houses, at least 9 houses, annuities of at least 310 Bezants per year, 4 pastures, 19 carrucatae of arable land (estimated $660 \mathrm{ha}$ ), moreover 5 casalia with associated land (estimated 2000 ha) and land estates near Mount Joy - approx. 400 ha which in total gives approx. 3,000 hectares of arable land (of course by no means com-

55 R. Röhricht, "Karten und Pläne zur Palästinakunde aus dem 7. bis 16. Jahrhundert," ZDPV 14 (1891) tab. 4, after p. 136.

56 Mayer, "Sankt Samuel," 58.

57 Mayer UKJ I, 423, no. 231.

58 Bezant - a gold coin weighing about $3.2 \mathrm{~g}$.

59 Mayer UKJ I, 491-492, no. 267 (cf. the confirmation of a donation by King Amalric I: Mayer UKJ II, 638, no. 369). Smaller donations also came from private individuals, e.g. an annuity of 10 Bezants from Odonis de Sancto Amando (Mayer, UKJ II, 635-636, no. 366). An interesting note about him cf. S. Runciman, A History of the Crusades (Cambridge: University 1951) II, 420.

60 Mayer UKJ II, 638, no. 370. Its location is unknown.

61 Mayer, "Sankt Samuel, " 65-66: based on the document of Baldwin V from 1185. 
parable to a similar amount of land in Europe today), which could have resulted in a profit of 153 tons of wheat, 117 tons of barley and 18 tons of peas net (not counting wine, olives or cattle husbandry). ${ }^{62}$ Although this sounds impressive, it only proves that St. Samuel belonged to the middle-income monasteries of the Holy Land. ${ }^{63}$

The popularity of this place, among pilgrims, is evidenced by the impressive infrastructure in their service, partially preserved to this day: places to rest, accommodation, stables, cisterns, workshops, warehouses, etc., a comprehensive, huge complex of buildings.

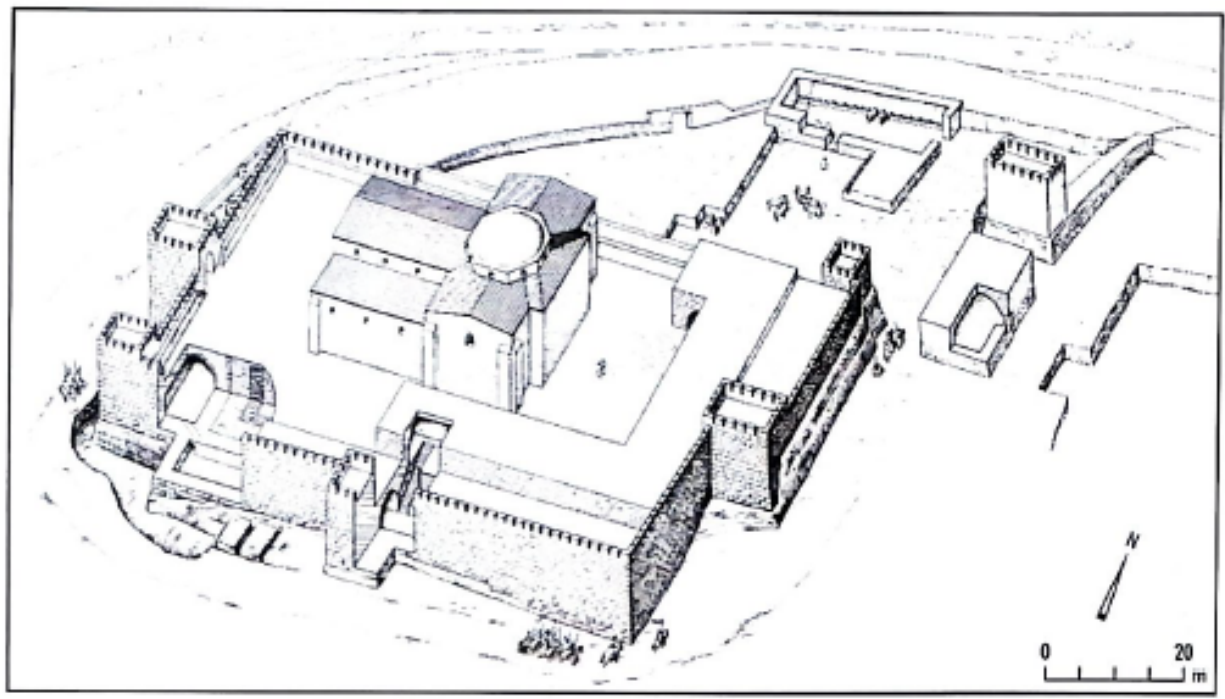

Reconstruction of the sanctuary and fortifications from the Crusades period. ${ }^{64}$

\section{The Decline of the Monastery of St. Samuel}

The heyday of the sanctuary came to an end in 1187, when the Muslim troops led by Saladin began to push the Crusaders out of the Holy Land. In one of the descriptions of Saladin's campaign there is a note about the incident of July 1187, when an elite Turkish force, numbering 400 warriors and escorting prisoners

\footnotetext{
62 These are only estimated figures. The understanding of the measures of the area of fields differed considerably, as did the yield that could be harvested.

63 Mayer, "Sankt Samuel," 66.

64 Source: Y. Magen, "Nebi Samwil," New Encyclopedia of Archaeological Excavations in the Holy Land (ed. E. Stern) (Jerusalem: Israel Exploration Society 2006) V, 1976.
} 
from the conquered castle Mirabel ${ }^{65}$ "brought them safely to the monastery of St. Samuel, which is located on Mount Silus, two miles from Jerusalem. From there, the Turkish escort with the prisoners went to Mount Joy near Jerusalem and was attacked there and forced to flee by the Knights Templars and men of Jerusalem." $" 66$

In the same anonymous account of the invasion of the Kingdom of Jerusalem in 1187, there is a list of places conquered and devastated by Saladin's army, including Mount Shiloh, ${ }^{67}$ in which place St. Samuel, the noblest and holiest of all prophets, was called by God from Heaven: "Samuel, Samuel," and with his innocent mouth, free from all the unclean plague of the world, he replied: "Speak, Lord, for your servant is listening." A monastery of Premonstratensian canons was built there, whose prayers are joined with those of Moses and Aaron, who ask God for forgiveness for our sins. ${ }^{68}$

The fortified monastery was conquered and devastated by Arab troops in late 1187. The evidence of the bloody course of those events may be found in the preserved memory of 7 Norbertine martyrs who were killed then. ${ }^{69}$ A less obvious testimony is the reminiscence of "All the Dead of St. Samuel" set in the martyrology of the Premonstratensians on 20 November, however, without giving a specific date of their martyrdom. ${ }^{70}$ Therefore, doubts arise. Jerusalem was conquered by Saladin on 2 October. It should be assumed that the poorly fortified monastery of St. Samuel on the way to Jerusalem should have been conquered earlier, and no more than 6 weeks later. Perhaps it is collective memory. It is also possible that the monastery was conquered or subjugated by Muslims before 2 October, in accordance with logic, but plundered only after the conquest of Jerusalem.

During the Third Crusade (1189-1192), the monastery was taken over by the Crusaders for a short time. This may be confirmed by the mention of King Richard the Lionheart visiting this place twice. His first visit to Mount Joy in June 1192 is mentioned by Ralph of Coggeshall (d. after 1227). He writes about

65 The fortress was built in 1152. Its ruins have endured to this day. During the Muslim period, a village called Majdal Yaba existed here until its destruction in 1948.

66 J. Stevenson (ed.), Libellus de expugnatione Terrae Sanctae per Saladinum (London: Longman et al.) (Rolls Series 66; London: Longman et al. 1875) 229-230.

67 The author of this testimony identifies Mons Gaudi with G. Scopus (he lists it next to Valley of Josaphat and Mount of Olives as a place where the troops besieging Jerusalem are supposed to pitch their tents - Stevenson, Libellus, 243). For a discussion of the arguments supporting the identification of Mons Gaudi with Mount Scopus in the 12th and partly in the 13th century, see: Kedar, "Jerusalem's Two Montes Gaudii," 7-12.

68 Stevenson, Libellus, 239-240.

69 A. Ernes, "Prémontrés," Dictionnaire de Théologie Catholique (eds. A. Vacant - E. MangenotÉ. Amann) (Paris: Letouzey et Ané 1936) XIII/1, 21.

70 "Commemoratio... et omnium defunctorum pertinentium ad ecclesiam ... sancti Samuelis transmarinae ecclesiae." Cf. R. van Waefelghem, Obituaire de l'abbaye de Premontre (Louvain: Impr. de P. Smeesters 1913) 222. 
a saintly monk (identified as a prior of the Orthodox monastery of St. Elijah), who was supposed to have saved the relics of the Holy Cross from Saladin's army, and then hide them in the monastery of St. Samuel. When King Richard arrived in the Holy Land, the monk led him to the walls of the monastery from where he retrieved the relics, and then handed them over to the king. ${ }^{71}$

For the second time, Richard the Lionheart was supposed to have appeared in the monastery of St. Samuel in July of the same year, in order to see the Holy City of Jerusalem from there and say prayers, since this is a custom of all pilgrims who head for Jerusalem... because from there one can see the Temple and the Sepulchre. ${ }^{72}$ According to other descriptions of this very visit of King Richard on Mount Joy, upon the news that his allies did not intend to attack Jerusalem, he was said to have covered his face with a shield (according to others, to have fallen to the ground), considering himself unworthy of looking at Jerusalem, if he was not able to recover it from the hands of the infidels. ${ }^{73}$ Everyone agrees on one thing: after the withdrawal of the allied forces, he himself did not have the strength to conquer Jerusalem, or to hold it in the event of victory, and having concluded this himself, "disappointed and angry," he retreated to Jaffa. ${ }^{74}$

Soon after King Richard's departure from Jaffa, Saladin's younger brother, Sultan Malik al-'Ädil, went to Mar Samwil to have a rest and seek healing. ${ }^{75}$ From then on, this place, with a very short break, remained under Muslim rule. As we know from the reports on the negotiations undertaken by Richard of Cornwall (son of John, King of England), "Bersamul" (= Nabi Samuel) together with other towns along the road from Lod to Jerusalem were surrendered to the Franks in $1241 .{ }^{76}$ However, it lasted only until in 1244 . It was probably the time when the fortifications around the monastery were demolished and the church itself was badly damaged. ${ }^{77}$

71 J. Stevenson (ed.), Radulphi de Coggeshall Chronicon Anglicanum (Rolls Series 66, London: Longman et al. 1875) 40-41.

72 Mention of this fact is preserved in The History of Heraclius, an Old French translation and a continuation of the Latin story of William of Tire from the 13th century, "Estoire d'Eracles Empereur et la Conqueste de la Terre d'Outreer," Recueil des Historiens des Croisades: Historiens Occidentaux (Paris: Imprimerie Impériale 1859) 184. Cf. M.R. Morgan (ed.), La continuation de Guillaume de Tyr (1184-1197) (Paris: Librairie Orientaliste Paul Geuthner 1982) 134-135.

73 Savignac - Abel, "Neby Samouil," 271.

74 "Estoire d'Eracles Empereur" 184; V. Guérin, Judée (Description géographique, historique et archéologique de la Palestine 1; Paris: Imprimérie Impériale 1868-1869) 368.

75 "Anecdotes et beaux traits de la vie du Sultan Youssof" (Salâh ed-Dîn)," Recueil des historiens des croisades: Historiens orientaux (Paris: Imprimerie nationale 1884) III, 336, 339, 351.

76 Matthaeus Parisiensis, Chronica Majora (ed. H.R. Luard) (Rolls Series 57; London: Longman 1877) IV, 142-143 (with footnote 10).

77 For a description of the activities of Muslim troops at that time, see: S. Runciman, A History of the Crusades (Cambridge: University Press 1954) III, 224-227. 


\section{Second Muslim Period}

The monks who managed to escape from the monastery on Mount Joy found refuge in Acre, ${ }^{78}$ from where they probably never returned to their mother monastery for a longer period. ${ }^{79}$ The numerous letters of Gervase of Acre, the Premonstratensian abbot, testify to the attempts at gaining the right to return to Mount Joy ${ }^{80}$ He turned to the popes, kings and patriarchs of Jerusalem, ${ }^{81}$ and even to Emperor Frederick II, asking for intercession and help. ${ }^{82}$ Unsuccessfully. The fate of the monastery on Mount Joy was sealed by the treaty concluded by Frederick II on 18 February 1219. According to the provisions of this document, all villages around Jerusalem were to remain under Muslim rule, including the hill of St. Samuel. ${ }^{83}$

However, the abbot of the Premonstratensian monastery in Acre, retained the title associated with the cult of St. Samuel on Mount Joy: Abbas Sancti Samuelis or, in a more solemn form, with the addition of de Monte Gaudio Praaemonstratensis ordinis Jerosolimitane diocesis. ${ }^{84}$ The relationships of the Premonstratensian abbey with the sanctuary of St. Samuel on Mount Joy, rather exclusively spiritual in the 13th century, is also evidenced by a seal on a letter from 1259, with the inscription: "S[igillum] Abbatis et Ecclesiae S. Samuelis d. Monte gaudii." ${ }^{85}$ Abbot [of the monastery] of St. Samuel of Monjoie is also mentioned in the list of suffragans of the Patriarch of Jerusalem compiled by John of Ibelin in the mid-60s of the 13th century. The author observes that although he

78 Savignac - Abel, "Neby Samouil," 271.

79 Pringle, The Churches of the Crusader 2, 87.

80 Over the period 1209-1220, then the bishop of Sées in Normandy until 1228.

81 R. Röhrich, Regesta No. 884; 906 et al. There are preserved, among others, two letters of Pope Gregory IX from 1238 (L. Auvray [ed.], Les Registres de Grégoire IX. Recueil des bulles de ce pape [Paris: Fontemoing 1907] II 917-918 [No. 4152] and: 1060-1061 [No. 4411]). In addition, other letters including those of Pope Innocent IV to the abbot of St. Samuel of Acre on the estates of the hospitallers (R. Röhricht from October 1250, Regesta 1193a and from February 1251 Regesta 1197) or Pope Alexander IV to the bishop of Tiberias and abbot of monastery of St. Samuel of Acre on the transfer of the monastery of St. Lazarus of Bethany to the Hospitallers from January 1256 (Röhricht, Regesta, 1244). In total (from various periods of his activity) as many as 149 letters of abbot Gervase have been preserved, which was a record result (Y.K. Seale, "Ten Thousand Women": Gender, Affinity, and the Development of the Premonstratensian Order in Medieval France [Diss. University of Iowa; Iowa City, IA 2016] 347-348).

82 Letter of 1227: J.L.A. Huillard-Breholles, Historia diplomatica Friderici secondi (Parisiis: Excudebant Plon Fratres 1852) III, 479-480.

83 Mayer, "Sankt Samuel," 41-42

84 Incl. in correspondence with Pope Gregory IX - see: Auvray, Les Registres de Grégoire IX, II, 917-918 (No. 4152), longer form 1060-1061 (No. 4411).

85 T. Tobler, Zwei Bücher Topographie von Jerusalem und seinen Umgebungen (Berlin: Reimer 1854) II, 675, n. 2. 
could wear a cross (= pectoral or crosier), but not a mitre or a ring. ${ }^{86}$ This list, however, probably refers to the status of the ecclesiastical hierarchy of the Kingdom of Jerusalem before 1187. The last document in which the title of "abbot [of the] St. Samuel of the Premonstratensian Order" is dated 23 February 1263 (... coram Johanne, S. Samuelis O. Pr. Abbate).$^{87}$ In the tradition of the monastery, the memory of 26 monks who died with their abbot Aegidius of Marle during the fall of Acre in 1291 is still kept ${ }^{88}$ However, this tradition has no confirmation in documents from that era. ${ }^{89}$

Also, after the sanctuary was recovered from the hands of the Crusaders, Christian pilgrims who appeared there from time to time, were shown the house and the crypt of Samuel's tomb and the church erected above them (and apparently not yet completely destroyed) church. ${ }^{90}$ Matthaeus Parisiensis marks the monastery of St. Samuel on Mount Joy on the map dated 1240-1253. From Burchard's account (1283) we can deduce that even several decades after the destruction of the monastery, Christian pilgrims used the name "ad sanctum Samuelem" on Mount Joy, which is known to us since ${ }^{91}$ the times of Theoderich..$^{92}$ The Italian Dominican Riccoldo da Monte di Croce (1289-1291) also writes about his visits to the "house of Samuel.".93

Unlike the Islamic tradition, in which the Prophet Samuel plays a rather marginal role, ${ }^{94}$ among Jews, he is one of the key figures in Israel's history.

86 "Livre de Jean d'Ibelin," Assises de Jérusalem ou recueil des ouvrages de jurisprudence composés pendant le XIIIe siècle dans les royaumes de Jérusalem et de Chypre (ed. M. Le Comte Beugnot) (Paris: Imprimerie royale 1841) I, 415: ...qui porte croce et non miter ne anel (unlike other abbots in Jerusalem).

87 Röhricht, Regesta No. 1323b.

88 N. Backmund, Monasticon Praemonstratense. Historia circariarum atque canoniarum candidi et canonici Ordinis Praemonstratensis (Straubing: Attenkofersche 1949) I, 405.

89 Mayer, "Sankt Samuel," 44.

90 Over the period 1244-1260, see: "Liber de Civitatibus Terrae Sanctae," Itinera Hierosolymitana Crucesignatorum (saec. XII - XIII) (ed. S. de Sandoli) (Jerusalem: Franciscan Printing 1978) IV, 364. Over the period 1261-1265, see: (anonymous, "Les Chemins et les Pelerinages de La Terre Sainte, Texte A," Itinéraires à Jérusalem et descriptions de la Terre Sainte rédigés en français au XIe, XIIe et XIIIe siècles (eds. H.V. Michelant - G. Raynaud) (Geneva: Fick 1882) 181. Cf. D. Pringle, "The Planning of Some Pilgrimage Churches in Crusader Palestine," World Archaeology 18 (1987) 348.

91 Burchardus de Monte Sion, "Descriptio Terrae Sanctae," 76.

92 H.V. Michelant - G. Raynaud (eds.), Itinéraires à Jerusalem et descriptions de la Terre Sainte rédigés en français aux XIe, XIIe et XIIIe siècles (Geneva: Fick 1882) 93, 196, 198. See also the chapter "Les pelrinages communes que Chrestiens fount en la Seinte Terre": F. Romanini - B. Saletti, I Pélrinages communes, i Pardouns de Acre e la crisi del regno crociato. Storia e testi (Padua: Libreriauniversitaria.it 2012) 122.

93 ... venimus in Ramatha in monte Effraym ... et visitavimus domum Samuelis. Riccoldo da Monte di Croce, "Liber Peregrinationis," Peregrinatores medii aevi quatuor (ed. J.C.M. Laurent) (Leipzig: Hinrichs Bibliopola 1864) 107.

94 The Prophet Samuel is a figure known to Muslims from the second surah of the Quran (verses 246-248). The prophet is not mentioned here by name, yet his identity can be guessed from the plot. 
The Prophet Samuel is seen as a rightful priest (cf. 1Chr 6:28), the last of the judges and the first of the prophets (cf. traces in the New Testament tradition: Acts 13:20; 3.24; Hebrews 11:32). Before Samuel, the prophets, in our understanding of the word, were usually called "seers" (ראה or חזה ), and the use of the term "nabi" (נביא see: 1Sam 9:9) started with Samuel. In rabbinic literature, he appears as an extremely wealthy wise man who travels from town to town and explains the Law to the people. In this context, a certain advantage of Samuel over Moses is indicated. When the latter wanted to know what the will of God was, he had to go to the tent of meeting, while God himself came to Samuel to reveal His will to him..$^{95}$ Samuel was also associated with the greatness of Israel. He was seen as a founder of the Kingdom of Israel, primarily through the anointment of David, but also as an instrument of God's punishment against the Amalekites. In the rabbinical tradition, he is also considered the author of the Book of Judges and Ruth and, of course, the Books of Samuel (later supplemented by Gad, cf. Talmudic treatise Baba Batra 14b-15b). It is hardly surprising that when some Christian monks were murdered and others left the place, the Jews, who avoided that place at the time when there was a Catholic church at the prophet's tomb, started to make pilgrimages here willingly and in large numbers. Although it remained under the supervision of Muslim authorities, they established their synagogue there. While some questioned the authenticity of the prophet's tomb, others believed it without reservations. In the following centuries, this place became one of the most important pilgrimage destinations for Jews (especially from nearby Jerusalem, but also from Mesopotamia, Syria, Anatolia and Egypt). ${ }^{96}$ Over time, pious wanderers from Diaspora came to the tomb of Samuel, and not to Jerusalem. Since the 13th century, references to the tomb of the Prophet Samuel have appeared in all Jewish lists of holy places, accounts of pilgrimages and journeys.

The Sanctuary of Samuel, mainly due to its fame, but probably also because of the profits it generated, was becoming increasingly important to Muslims as well. Throughout this period, there occurred both minor and major conflicts between the two communities. The turning point came in the 18th century, when the Sanctuary (probably already devastated and desolated for a long time ${ }^{97}$ ) was turned into a mosque, and Jews had limited access, and during certain periods were even strictly forbidden from entering. It is worth mentioning that at least at

There are no records of the death and burial place of Samuel in the Quran. Cf. A. Yusuf Ali, The Holy Qur'an: Text, Translation and Commentary (Beltsville, MD: Amana Publications 2002) n. 278 to v. 246.

95 E.G. Hirsch - W. Bacher - J. Zallel Lauterbach, "Samuel," Jewish Encyclopedia (eds. I. Singer C. Adler) (Funk \& Wagnalls 1906) XI, 7.

96 See: J. Ben-Dov, נבי סמואל (Nabi Samuel) (Tel Aviv-Yafo: Hameuchad 2006) 62-63.

$97 \mathrm{Nau}(\mathrm{d})$, Voyage nouveau, 497-498. 
the end of the 17th century, Christian pilgrims were also strictly forbidden to enter the sanctuary. ${ }^{98}$ At the time of growing interest in the Orient, European travellers and explorers began to arrive with increasing frequency at Mount Samuel. The first documentation of the site was prepared, and surface studies were conducted. Around the sanctuary, there was a small, poor village inhabited by over one hundred people.

Two significant battles were fought for the control of that hill in the 20th century. The first battle, between the Ottoman Turks and the British army, was waged in 1917.99 It was during these battles that Nabi Samuel Hill was heavily bombed, resulting in severe damage not only to the Arab village, but also to the remains of the Crusades times. ${ }^{100} \mathrm{Nabi}$ Samuel was attacked for the second

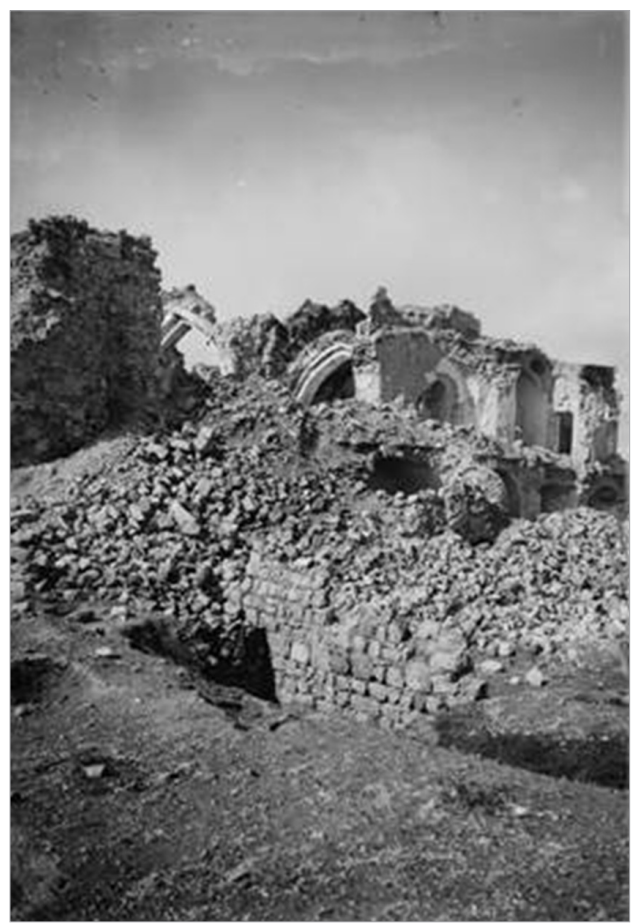

War view of Nabi Samuel. Ruined mosque 1917 or $1918 .^{101}$ time in April 1948, when a detachment of the Haganah, a paramilitary Jewish organization fighting for the establishment of the state of Israel, fought a fierce battle, unsuccessfully trying to conquer the Palestinian hill. ${ }^{102}$ After 1948, Nabi Samuel remained part of the territory of Jordan and Israelis were forbidden from entering the sanctuary.

$98 \mathrm{Nau}(\mathrm{d})($ Voyage nouveau, 498) also writes that some violated this prohibition even with the assistance of Turks.

99 For the British, the Battle of Nabi Samuel was an introduction to the seizure of Jerusalem. For a detailed description of the activities, see: A. Bruce, The Last Crusade, the Palestine Campaign in the First World War (London: Murray 2002) 151-163.

100 The badly damaged church was renovated by the British in 1921.

101 Matson photograph collection: American Colony. Photo Department, War views of Neby Samuel Mizpah. Ruined mosque. https://www.loc.gov/item/2019695924/ [access: 03.05.2021].

102 The attack on Nabi Samuel was part of an operation code-named Yevusi. Within Yevusi, the fighting for the hill lasted from 22 to 23 April 1948 and ended with the retreat of the Israeli troops. 


\section{Ending}

The situation drastically changed after 1967, when the Israeli army had seized the territory of Nabi Samuel. In 1971, the previous inhabitants were displaced, and a national park was established around the mosque, with a place of prayer for Jews within the mosque itself, and a synagogue arranged in the burial crypt. A somewhat forgotten sanctuary began to incite emotions anew. Due to the archaeological works and the first Hebrew publications relating to this place, its importance not only or not so much for religion, but also for the history of Jews and Judaism was recognised. Protesting against the actions of Israel, Muslims started to arrive at this place increasingly often.

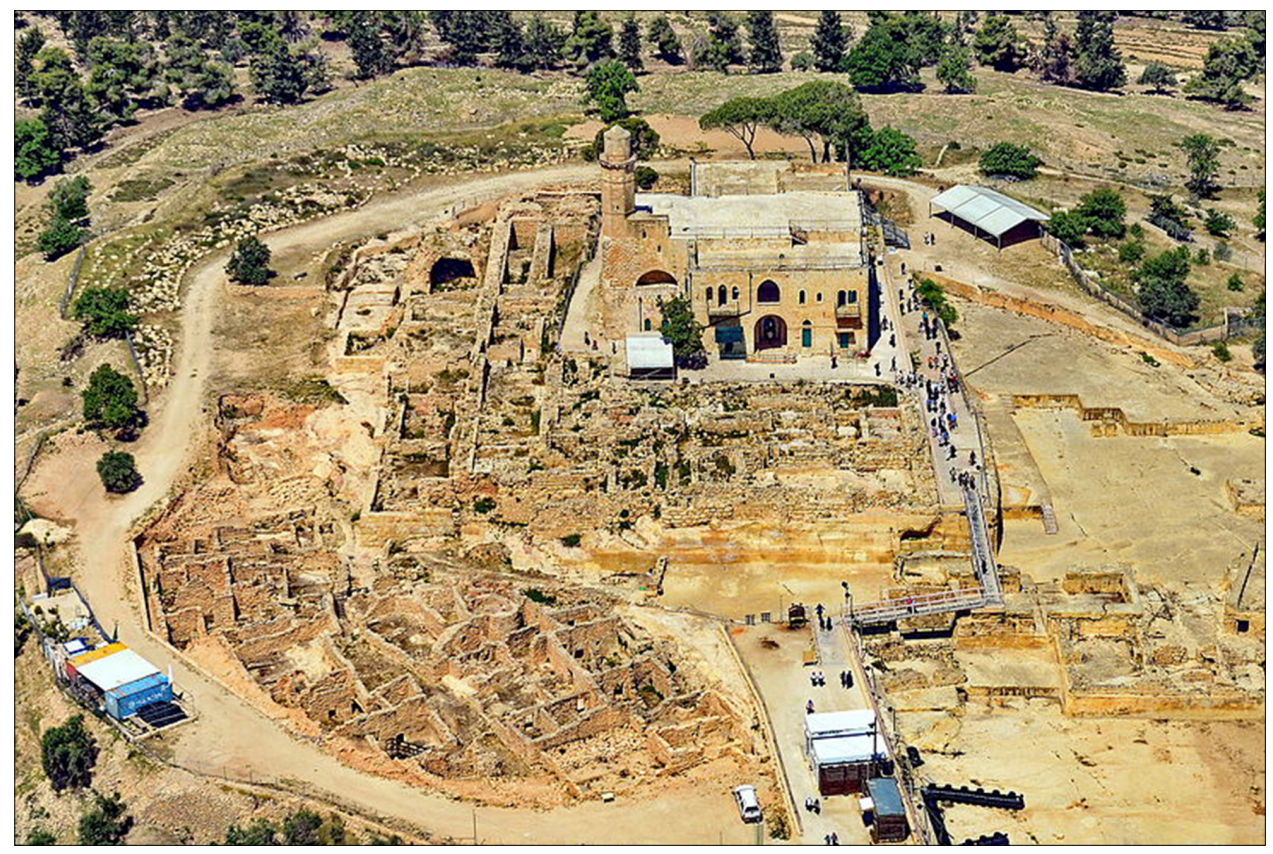

Nabi Samuel (2014). Fot. by Avraham Graicer. ${ }^{103}$

Currently in Nabi Samuel, a mosque and a synagogue exist in the same building, but in different rooms, both focused on the tomb of the Prophet Samuel, and more precisely on his two cenotaphs standing one above the other.

103 Source: https://commons.wikimedia.org/wiki/File:NABI_SAMUEL_3.jpg [access: 3.05.2021] 
This place deserves attention not only because of the cult of the Prophet Samuel, but also for its exceptionally interesting history and the role it played in each of the religious communities co-creating this place. Unfortunately, currently, the founders of the sanctuary, and then for many centuries its hosts Christians, are the least interested in it.

\section{Bibliography}

Abel, F.-M., “Attarah et Nasbeh au moyen âge,” Journal of the Palestine Oriental Society 11 (1931) $141-143$.

"Alberti Aquensis Historia Hierosolymitana," Recueil des historiens des croisades. Historiens occidentaux (ed. Académie des Inscriptions et Belles-Lettres) (Paris: Imprimerie nationale 1879) IV, 265-714.

"Anecdotes et beaux traits de la vie du Sultan Youssof (Salâh ed-Dîn)," Recueil des historiens des croisades: Historiens orientaux (ed. Académie des Inscriptions et Belles-Lettres) (Paris: Imprimerie nationale 1884) III, 1-370.

"Estoire d'Eracles Empereur et la Conqueste de la Terre d'Outremer," Recueil des Historiens des Croisades: Historiens Occidentaux (ed. Académie des Inscriptions et Belles-Lettres) (Paris: Imprimerie Impériale 1859) II.

Adler, M.N. (ed.), The Itinerary of Benjamin of Tudela. Critical Text, Translation and Commentary (Londyn: Frowde 1907).

Auvray, L. (ed.), Les Registres de Grégoire IX. Recueil des bulles de ce pape (Paris: Fontemoing 1907) II.

Backmund, N., Monasticon Praemonstratense. Historia circariarum atque canoniarum candidi et canonici Ordinis Praemonstratensis (Straubing: Attenkofersche 1949) I.

Ben-Dov, J., נבי סמואל (Nabi Samuel) (Tel Aviv-Yafo: Hakibbutz Hameuchad 2006).

Bernard, J.H. (trans.), Theodosius (A.D. 530). De situ terrae sanctae (The Library of the Palestine Pilgrims' Text Society; London: Palestine Pilgrims' Text Society 1893).

Bruce, A., The Last Crusade, the Palestine Campaign in the First World War (London: Murray 2002). Burchardus de Monte Sion, "Descriptio Terrae Sanctae," Peregrinatores medii aevi quatuor (ed. J.C.M. Laurent) (Leipzig: Hinrichs 1864) 1-101.

Dalman, G., Jerusalem und sein Gelände (Gütersloh: Bertelsmann 1930).

Dawid, A., "Jewish Travelers from Europe to the East. 12th-15th Centuries," Miscelánea de Estudios Árabes y Hebraicos: Sección Hebreo 62 (2013) 11-39.

Delaborde, H. F., Chartes de Terre Sainte Provenant de l'Abbaye de N.-D. de Josaphat (Paris: Thorin 1880).

Delaville le Roulx, J., “L'Ordre de Montjoye," Revue de l'Orient Latin 1 (1893) 42-57.

Delaville le Roulx, J., Cartulaire général de l'Ordre des Hospitaliers de Saint-Jean de Jérusalem (Paris: Leroux 1894) I.

Dulska, A.K., Diaspora żydowska na Bliskim Wschodzie oczami sefardyjskiego podróżnika Beniamina z Tudeli (Kraków: Księgarnia Akademicka 2015). 
Ehrlich, M., "The Route of the First Crusade and the Frankish Roads to Jerusalem during the 12th Century," Revue Biblique 113/2 (2006) 263-283.

Elitzur, Y., 'מקור המסורת על 'נבי סמואל ("Sources of the 'Nebi-Samuel' Tradition”), Cathedra. For the History of Eretz Israel and Its Yishuv 31 (1984) 75-90.

Ernes, A., "Prémontrés," Dictionnaire de Théologie Catholique (eds. A. Vacant - E. Mangenot É. Amann) (Paris: Letouzey et Ané 1936) XIII/1, 2-31.

Feldstein, A. et al., "Southern Part of the Maps of Ramallah and el-Bireh and Northern Part of the Map of Ein Karem," Archaeological Surveys in the Hill Country of Benjamin (eds. I. Finkelstein - Y. Magen) (Jerusalem: Israel Antiquities Authority 1993) 133-263 [Hebrew, English abstract].

Folda, J., "Melisende of Jerusalem: Queen and Patron of Art and Architecture in the Crusader Kingdom," Reassessing the Roles of Women as 'Makers' of Medieval Art and Architecture (ed. T. Martin) (Leiden: Brill 2012) 429-477.

Forey, A.J., "The Order of Mountjoy," Speculum 46/2 (1971) 250-266.

Geyer, P. (ed.), Itinera Hierosolymitana saeculi IIII-VIII (Corpus Scriptorum Ecclesiasticorum Latinorum XXXVIII; Vindobonae: Tempsky 1898).

Gibson, S. - Har-Pele, M., "On the Location of Mons Gaudii in Northern Jerusalem," Strata. Bulletin of the Anglo-Israel Archaeological Society 37 (2019) 113-140.

de Goeje, M.J., Biblioteca Geographorum Arabicorum (Leiden: Brill 1870) III.

Guérin, V., Judée (Description géographique, historique et archéologique de la Palestine 1; Paris: Imprimérie Impériale 1868-1869).

Hamilton, B., "Rebuilding Sion: The Holy Places of Jerusalem in the Twelfth Century," Studies in Church History 14 (1977) 105-116.

Hieronymus, "Liber contra Vigilantium," Sancti Eusebii Hieronymi, Stridonensis Presbyteri, Opera omnia (ed. J.P. Migne) (Patrologia Latina 23; Paris: Migne 1845) 337-352.

Hirsch, E.G. - Bacher, W. - Zallel Lauterbach, J., "Samuel," Jewish Encyclopedia (eds. I. Singer C. Adler) (New York: Funk \& Wagnalls 1906) XI, 5-8.

Huillard-Bréholles, J.L.A., Historia diplomatica Friderici secundi (Parisiis: Excudebant Plon Fratres 1852) III.

Institute for Historical Justice and Reconciliation, Sacred Sites in the Holy Land. Historical and Religious Perspectives (The Hague: Institute for Historical Justice and Reconciliation 2011).

Kedar, B.Z., "Jerusalem's Two Montes Gaudii," Crusader Landscapes in the Medieval Levant. The Archaeology and History of the Latin East (eds. M. Sinibaldi et al.) (Cardiff: University of Wales Press 2016) 3-20.

Klein, H. A., "Sacred Relics and Imperial Ceremonies at the Great Palace of Constantinople," Visualisierungen von Herrschaft. Frühmittelalterliche Residenzen - Gestalt und Zeremoniell (ed. F.A. Bauer) (= BYZAS 5; İstanbul: Ege Yayınları 2006) 79-99.

de Lagarde, P. (ed.), Onomastica sacra (Gottingae: Rente 1870).

Le Strange, G. (ed., trans.), Palestine under the Moslems. A Description of Syria and the Holy Land from A.D. 650 to 1500 (London: Watt for the Committee of the Palestine Exploration Fund 1890).

Leclercq, J. - Rochais, H. (eds.), Sancti Bernardi Opera (Rome: Cisterciennes 1979) VIII.

"Liber de Civitatibus Terrae Sanctae," Itinera Hierosolymitana Crucesignatorum (saec. XII-XIII) (ed. S. de Sandoli) (Jerusalem: Franciscan Printing Press 1978) IV, 340-367. 
"Livre de Jean d'Ibelin," Assises de Jérusalem ou recueil des ouvrages de jurisprudence composés pendant le XIIIe siècle dans les royaumes de Jérusalem et de Chypre (ed. M. Le Comte Beugnot) (Paris: Imprimerie royale 1841) I, 21-430.

Lohmann, P., "Studien aus dem Deutschen evang. Institut für Altertumswissenschaft in Jerusalem. 29. Archäologisches von en-nebi samwīl," Zeitschrift des Deutschen Palästina-Vereins 41/34 (1918) 117-157.

Luard, H.R. (ed.), Matthcei Parisiensis, monachi Sancti Albani, Chronica majora (Rolls Series 57/4; London: Longman et al. 1877).

Mabillon, D.J. (ed.), “Gaufridus Claraevallensis. Vita Bernardi. Liber III,” Sancti Bernardi Abbatis Clarae-Vallensis opera omnia (Patrologia Latina 185; Paris: Migne 1860)

Mabillon, D.J. (ed.), Sancti Bernardi Abbatis Clarae-Vallensis opera omnia (Patrologia Latina 182; Paris: Migne 1859).

Magen, Y., "Nebi Samwil, Where Samuel Crowned Israel's First King," Biblical Archaeology Review 34/3 (2008) 36-54, 78-79.

Magen, Y., "Nebi Samwil," New Encyclopedia of Archaeological Excavations in the Holy Land (ed. E. Stern) (Jerusalem: Israel Exploration Society 2006) V, 1972-1976.

Magen, Y. - Dadon, M.M., "Nebi Samwil (Montjoie)," One Land, Many Cultures. Archaeological Studies in Honour of Stanislao Loffreda (eds. G.C. Bottini - L. Di Segni - L.D. Chrupcala) (Jerusalem: Franciscan Printing Press 2003) 123-138.

Mayer, H.E. (ed.), Die Urkunden der lateinischen Könige von Jerusalem. Altfranzösische Texte erstellt von Jean Richard (Monumenta Germaniae Historica. Diplomata regum Latinorum Hierosolymitanorum 1-4; Hanover: Hahn 2010) [= Mayer UKJ] I-II.

Mayer, H.E., "Sankt Samuel auf dem Freudenberge und sein Besitz nach einem unbekannten Diplom König Balduins V," Quellen und Forschungen aus italienischen Archiven und Bibliotheken 44 (1964) 35-71.

Mayer, H.E., Kreuzzüge und lateinischer Osten (London: Variorum 1983).

Meehan, D. (ed.), Adamnan's De Locis Santis (Scriptores Latini Hiberniae 3; Dublin: Dublin Institute for Advanced Studies 1983).

Michelant, H.V. - Raynaud, G. (eds.), "Les Chemins et Les Pelerinages de La Terre Sainte, Texte A," Itinéraires à Jérusalem et descriptions de la Terre Sainte rédigés en français au XIe, XIIe et XIIIe siècles (Geneva: Fick 1882) 177-188.

Migne, J.P. (ed.), Nicephori Callisti Xanthopuli Ecclesiasticae Historiae (Patrologiae Cursus Completus. Series Graeca 146) (Parisiis: Migne 1865).

Morgan, M.R. (ed.), La continuation de Guillaume de Tyr (1184-1197) (Paris: Librairie Orientaliste Paul Geuthner 1982).

Naud [Nau], M., Voyage nouveau de la Terre-Sainte. Enrichi de plusieurs remarques particulieres qui servent à l'intelligence de la Sainte Ecriture (Paris: Pralard 1679).

Prawer, J., Histoire du Royaume latin de Jérusalem (trans. from Hebrew G. Nahon) (Paris: Centre National de la Recherche Scientif 1975) II.

Prawer, J., The History of the Jews in the Latin Kingdom of Jerusalem (Oxford: Clarendon 1988).

Pringle, D., "The Planning of Some Pilgrimage Churches in Crusader Palestine," World Archaeology 18 (1987) 341-362.

Pringle, D., The Churches of the Crusader Kingdom of Jerusalem. A Corpus (Cambridge: Cambridge University Press 1992-1993) I-II. 
Procopius, On Buildings. General Index (trans. H.B. Dewing - G. Downey) (Loeb Classical Library 343; Cambridge, MA: Harvard University Press 1940).

Reiner, E., עלייה ועלייה לרגל לארץ ישראל 1099-1517 (Pilgrims and Pilgrimage to Eretz Yisrael 1099-1517) (Diss. Hebrew University; Jerusalem 1988).

Rey, E.G., Géographie historique de la Syrie au temps des croisades. Le domaine royal. Les colonies franques de Syrie aux XIIme et XIIIme siècles (Paris: Alphonse Picard 1883).

Riccold de Monte Croce, Pérégrination en Terre Sainte et au Proche Orient. Lettres sur la chute de Saint-Jean d'Acre (ed., trans. R. Kappler) (Paris: Champion 1997).

Riccoldo da Monte di Croce, "Liber Peregrinationis," Peregrinatores medii aevi quatuor (ed. J.C.M. Laurent) (Leipzig: Hinrichs Bibliopola 1864) 101-141.

Röhricht, R. (ed.), Regesta Regni Hierosolymitani (MXCVII-MCCXCI) (Oeniponti: Libraria Academica Wageriana 1893).

Röhricht, R., "Karten und Pläne zur Palästinakunde aus dem 7. bis 16. Jahrhundert," Zeitschrift des Deutschen Palästina-Vereins 14 (1891) 8-11, 87-92, 137-141.

Romanini, F. - Saletti, B., I Pélrinages communes, i Pardouns de Acre e la crisi del regno crociato. Storia e testi (Padua: Libreriauniversitaria.it 2012).

de Rozière, E., Cartulaire de l'Eglise du Saint Sépulcre de Jérusalem (Paris: Imprimerie Nationale 1849).

Runciman, S., A History of the Crusades (Cambridge: Cambridge University Press 1951-1954) II-III.

Savignac, R. - Abel, F.M., "Neby Samouil," Revue Biblique. Nouvelle série 9/2 (1912) 267-279.

Schwarz, P., "En-nebi Samwil in einer Schilderung bei Mukaddasi," Zeitschrift des Deutschen Palästina-Vereins 41/3-4 (1918) 157-161.

Seale, Y.K., "Ten Thousand Women." Gender, Affinity, and the Development of the Premonstratensian Order in Medieval France (Diss. University of Iowa; Iowa City, IA 2016).

Sharon, M. (ed.), Corpus Inscriptionum Arabicarum Palaestinae (Leiden - Boston, MA: Brill 2004) III.

Stevenson, J. (ed.), Libellus de expugnatione Terrae Sanctae per Saladinum (Rolls Series 66; London: Longman et al. 1875) 209-262.

Stevenson, J. (ed.), Radulphi de Coggeshall Chronicon Anglicanum (Rolls Series 66; London: Longman et al. 1875) 1-208.

Stewart, A. (trans.), Felix Fabri (Circa 1480-1483 AD) (The Library of the Palestine Pilgrims' Text Society 7; London: Palestine Pilgrims' Text Society 1896) I/1.

Stewart, A. (trans.), Theoderich's Description of the Holy Places (Circa 1172 A.D.) (The Library of the Palestine Pilgrims' Text Society; London: Palestine Pilgrims' Text Society 1891) V/4.

Stubbs, W. (ed.), Itinerarium peregrinorum et gesta regis Ricardi (London: Longman 1864).

Tobler, T. (ed.), Theoderici libellus de locis sanctis, ed. circa 1772, cui accedunt breviores aliquot descriptiones Terrae Sanctae (Paris: St. Gallen 1865).

Tobler, T., Zwei Bücher Topographie von Jerusalem und seinen Umgebungen (Berlin: Reimer 1854) II.

van Waefelghem, R., Obituaire de l'abbaye de Prémontré (Louvain: Impr. de P. Smeesters 1913).

Whitby, M. - Whitby, M. (trans., eds.), Chronicon Paschale 284-628 AD (Translated Texts for Historians 7) (Liverpool: Liverpool University Press 1989). 
Wilson, C. W., The Pilgrimage of the Russian abbot Daniel in the Holy Land (The Library of the Palestine Pilgrims' Text Society; London: Palestine Pilgrims' Text Society 1895).

Wright, T., Early Travels in Palestine. Comprising the Narratives of Arculf, Willibald, Bernard, Scewulf, Sigurd, Benjamin of Tudela, Sir John Maundeville, De la Brocquière, and Maundrell (London: Woodfall \& Son 1848).

Yusuf Ali, A., The Holy Qur'an. Text, Translation and Commentary (Beltsville, MD: Amana Publications 2002). 
